\title{
Teori Kritis Habermas dan Kebijakan Merdeka Belajar
}

\author{
Gerald Moratua Siregar ${ }^{1}$ \\ ${ }^{1}$ Magister Filsafat Keilahian, Fakultas Teologi UKDW Yogyakarta, Indonesia \\ E-mail: geraldonk@gmail.com ${ }^{1}$
}

\begin{abstract}
Abstrak
Akhir tahun 2019, Menteri Pendidikan dan Kebudayaan Nadiem Anwar Makarim mencanangkan kebijakan Merdeka Belajar untuk mengoptimalkan implementasi kurikulum yang berbasis kompetensi. Satu pertanyaan penting yang menyusul dari diterapkannya kebijakan baru Merdeka Belajar adalah seberapa jauh kebijakan ini dapat berdampak dan bertahan? Sebagai praktisi pendidikan, penulis melihat sebuah permasalahan, bahwa selama ini, pembaruan-pembaruan kurikulum berbasis kompetensi tersebut tidak dapat berjalan secara optimal. Penelitian ini bertujuan untuk merekomendasikan Teori Kritis Habermas sebagai pendekatan alternatif agar implementasi kurikulum berbasis kompetensi dapat berjalan efektif dan berkesinambungan. Metode yang digunakan di dalam penelitian ini adalah kualitatif dengan melakukan kajian pustaka. Literatur dikumpulkan dengan menggunakan mesin pencari literatur seperti Google Scholar, ResearchGate, dan Academia.edu. Hasil penelitian menunjukkan bahwa Teori Kritis Habermas dapat dijadikan pedoman alternatif, baik bagi satuan pendidikan maupun bagi pendidik untuk mengimplementasikan kebijakan Merdeka Belajar dengan optimal.
\end{abstract}

Kata kunci: pendidikan; kurikulum berbasis kompetensi; merdeka belajar; teori kritis Habermas.

\begin{abstract}
At the end of 2019, the Minister of Education of the Republic of Indonesia, Nadiem Anwar Makarim, launched the Merdeka Learning policy to optimize the implementation of a competencybased curriculum. One important question that follows from this policy is to what extent this policy can impact and last? As an education practitioner, the author sees a problem, that by far, the renewal of the competency-based curriculum has not been able to run optimally. This research aims to recommend Habermas' Critical Theory as an alternative approach so that the implementation of a competency-based curriculum will be effective and sustainable. The method used in this research is a qualitative one by conducting a literature review. The reviewed meterials were collected using literature search engines such as Google Scholar, ResearchGate, and Academia.edu. The result of this research shows that Habermas's Critical Theory can be used as an alternative guide for both education units (primary and high schools) and educators to optimally implement the Merdeka Learning policy.
\end{abstract}

Keywords: education; competency-based curriculum; merdeka belajar policy; Habermas' critical theory.

\section{Pendahuluan}

Dalam kurun waktu tiga puluh tahun terakhir ini, dunia kerja secara global sudah beranjak dari era industrial lama (kata "lama" penulis tambahkan agar tidak rancu dengan istilah revolusi industri 4.0 yang terbaru) ke era kewirausahaan. Dalam era industrial lama, kebanyakan profesi telah memiliki pola pekerjaan yang didesain sesuai kebutuhan perusahaan. Pekerja hanya dituntut untuk memenuhi perintah dan menjalankannya sesuai pola. Sementara dalam dunia kerja era kewirausahaan dan era revolusi industri 4.0, setiap insan harus mampu menciptakan polanya masing-masing sesuai dengan bidang yang digeluti. Semakin kreatif dan unik, maka akan semakin memiliki daya saing. Untuk keperluan itu, masyarakat Indonesia perlu dididik dan dilatih agar memiliki kompetensi yang utuh, mampu berpikir kritis dan kreatif, dapat berkomunikasi dengan baik, serta dapat berkolaborasi (Sumarno \& Gimin, 2019).

Dalam kaitan itu, pendidikan dasar dan menengah di Indonesia telah mengalami perubahan sistem dan kurikulum dari Kurikulum Berbasis Materi (KBM) ke Kurikulum Berbasis Kompetensi (KBK) sejak tahun 2004. Dari tahun 2004 sampai saat ini, KBK telah mengalami pembaruan beberapa kali, antara lain dengan diberlakukannya Kurikulum Tingkat Satuan Pendidikan (KTSP) tahun 2006 dan Kurikulum Nasional (Kurnas) tahun 2013. Intinya, penyempurnaan kurikulum tersebut berbasis pada kompetensi, bukan pada materi. Pemerintah, dalam hal ini Kementerian Pendidikan dan Kebudayaan (Kemendikud), melakukan 
penyempurnaan, karena dalam pelaksanaannya KBK belum optimal dan maksimal. Tradisi dan budaya pembelajaran berbasis KBM masih sangat melekat dan tidak mudah untuk diubah. Sebagai contoh, guru sebagai ujung tombak perubahan kurikulum ini wajib juga mengubah paradigma dan cara mengajar pada kurikulum lama kepada pola kurikulum yang baru. Guru tidak bisa lagi mengajar dengan cara yang lama, yaitu sebagai sumber wawasan, karena wawasan sudah dengan mudah dapat diperoleh pada media. Guru membutuhkan strategi yang tepat untuk menjawab perubahan-perubahan ini. Sebisa mungkin tidak boleh terjadi kesenjangan antara konteks masa kini dan cara mengajar guru (Fuaddudin, 2020).

Menteri Pendidikan dan Kebudayaan, Nadiem Anwar Makarim, pada masa awal kepemimpinannya telah memulai untuk membudayakan kebijakan Merdeka Belajar untuk mengoptimalkan perubahan itu. Bagi sekolah dan para praktisi di dunia pendidikan, Merdeka Belajar merupakan kebijakan yang radikal. Salah satunya adalah dengan diberlakukannya pergantian model Ujian Nasional (UN) yang selama ini sudah dilaksanakan lebih dari lima puluh tahun (dengan istilah yang berbeda-beda).

Selain masalah UN, masih ada beberapa hal lain lagi yang diajukan oleh Makarim, yang merupakan bagian dari perubahan-perubahan yang cukup radikal. la juga mengusulkan tiga hal berikut: pergantian Ujian Sekolah Berstandar Nasional (USBN) menjadi ujian lokal satuan pendidikan, penyusunan RPP yang lebih ringkas, serta sistem zonasi dalam Penerimaan Peserta Didik Baru (PPDB) yang lebih fleksibel. Jadi secara total terdapat empat kebijakan baru sebagai wujud penerapan Merdeka Belajar.

Satu pertanyaan penting yang menyusul dari diterapkannya kebijakan Merdeka Belajar adalah seberapa jauh kebijakan ini dapat berdampak dan bertahan? Sepanjang enam belas tahun pelaksanaan kurikulum berbasis kompetensi ini, pemerintah (Kemendikbud), satuan pendidikan, dan praktisi pendidikan masih menemukan berbagai kendala untuk menerapkan kurikulum ini secara optimal. Dalam pandangan penulis, kendala yang paling utama terletak pada besarnya pengaruh kurikulum lama (KBM) yang telah bertahun-tahun secara mendalam membentuk paradigma dan praksis pemerintah, satuan pendidikan, pendidik, dan orangtua/wali peserta didik.

Jika dilihat dari tren penyempurnaan kurikulum bagi sekolah dasar dan menengah selama ini, maka ada kemungkinan kebijakan baru ini akan bersifat sementara. Oleh sebab itu diperlukan sebuah perubahan yang radikal. Untuk itu, melalui artikel ini penulis mengajukan relevansi antara kebijakan Merdeka Belajar dan Teori Kritis Habermas. Asumsi awal penulis adalah bahwa Teori Kritis Habermas dapat menjadi konsep yang implementatif dalam menjalankan kebijakan Merdeka Belajar dengan baik. Salah satu konsep yang ditawarkan dalam Teori Kritis Habermas adalah mengambil jarak dengan suatu tradisi agar seseorang dapat melakukan refleksi kritis terhadap tradisi tersebut, dan kemudian mengambil sikap dan tindakan yang radikal demi sebuah perubahan (Hardiman). Jika dikorelasikan dengan konteks pendidikan di Indonesia, maka para pelaku pendidikan seharusnya dapat membebaskan diri dari ikatan tradisi dan konsep yang lama, agar konsep dan praktik pendidikan yang lebih baru dapat dioptimalkan.

Tujuan dari artikel ini adalah untuk membuka wacana bahwa melalui Teori Kritis Habermas, kebijakan Merdeka Belajar dapat diimplementasikan secara efektif dan memiliki dampak yang berkelanjutan.

\section{Metode}

Penelitian ini merupakan penelitian kualitatif dengan menggunakan kajian pustaka tentang Teori Kritik Habermas dan konsep pendidikan masa kini yang sejalan dengan kebijakan Merdeka Belajar. Literatur riset dikumpulkan dengan menggunakan mesin pencari literatur seperti Google Scholar, ResearchGate, dan Academia.edu. Pada pembahasan penelitian, hasil kajian literatur yang diperoleh, baik tentang permasalahan pendidikan di Indonesia, konsep Merdeka Belajar, maupun tentang Teori Kristis Habermas akan dikorelasikan guna mendapatkan implikasi yang bersifat implementatif dan aplikatif.

\section{Hasil dan Pembahasan}

a. Hasil Penelitian

1) Kurikulum Berbasis Kompetensi Belum Maksimal: Suatu Urgensi Merdeka Belajar

Kurikulum Berbasis Kompetensi (KBK) kali pertama diterapkan pada tahun 2004, yang kemudian berkembang menjadi KTSP pada tahun 2006, dan disempurnakan menjadi Kurnas pada tahun 2013. Ketiganya merupakan kurikulum berbasis kompetensi. Melalui kurikulum ini, 
pendidikan di Indonesia diharapkan dapat menghasilkan lulusan yang lebih terampil dan kompeten.

KBK merupakan pengganti kurikulum sebelumnya yang sudah dipakai hampir empat dekade, yaitu Kurikulum Berbasis Materi (KBM). KBM adalah kurikulum yang menekankan pada pemberian materi ajar yang seragam kepada semua siswa, yang menjelaskan bahwa pada akhir pembelajaran, pendidik akan memberikan evaluasi dan tagihan penilaian kognitif yang juga seragam kepada semua peserta didik. KBM berorientasi pada guru dan materi ajar. Dalam KBM, siswa yang berhasil adalah mereka yang mampu mengingat semua materi dengan baik.

Sedangkan dalam KBK, penekanan pendidikan terletak pada kemampuan/kecerdasan siswa yang notabene berbeda-beda. Dalam proses belajar mengajar, guru bertugas sebagai fasilitator bagi peserta didik untuk mengembangkan bakat dan kemampuan peserta didik. Bakat dan kemampuan siswa tersebut dieksplorasi agar dapat berdialog dengan objek ilmu pengetahuan, yang kemudian diejawantahkan dalam bentuk kompetensi yang tentunya berbedabeda juga. Intinya, tidak semua peserta didik memiliki minat dan bakat yang sama. Artinya, ada kebutuhan (needs and demands) yang berbeda dari setiap peserta didik (Sudiarta, 2003). Dengan demikian, orientasi pembelajaran bukan lagi terletak pada guru dan materi ajar, melainkan pada siswa berdasarkan potensi dan minat yang dimilikinya. Tagihan penilaian pun seharusnya tidak lagi seragam, dan bukan lagi pada ranah kognitif saja, tetapi juga pada ranah psiko-motorik (praktek) dan afektif (sikap). Dalam kurikulum yang lama, peserta didik akan berkata: "Saya tahu", namun pada kurikulum yang baru peserta didik akan berkata: "Saya tahu dan saya bisa".

Konsep tentang KBK sebenarnya sudah sejak lama dipikirkan untuk diterapkan di Indonesia. Dalam sebuah buku berjudul "Belajar adalah Berubah" yang diterbitkan oleh Departemen Pendidikan dan Kebudayan pada tahun 1979, dituliskan bahwa proses pembelajaran harusnya berpusat pada siswa dan bukan pada guru. Jika pendidikan berpusat pada guru, maka gurunya yang akan lebih giat, dan dengan sendirinya siswa akan menjadi lebih pasif. Oleh sebab itu, untuk mengaktifkan proses belajar siswa, maka guru dituntut untuk mengenali kebutuhan belajar siswa yang beragam (Depdikbud, 1979).

Jadi, konsep KBK sudah dipikirkan sejak lama, serta telah sesuai dengan perkembangan era kewirausahaan. Sayangnya, sebagaimana disebutkan di atas, penerapannya belum maksimal. KBK masih berjalan di bawah bayang-bayang KBM. Paradigma pendidikan di Indonesia masih menekankan pentingnya penilaian kognitif dan sistem ranking yang tinggi. Selama ini, paradigma itu justru dilestarikan oleh pemerintah. Pemerintah masih menerapkan Ujian Nasional (UN), dan dengan sendirinya nilai UN dijadikan standar untuk kelulusan, saringan masuk Perguruan Tinggi (PT), serta untuk penetapan ranking sekolah. Sekolah sebagai satuan pendidikan, demi meraih prestise, secara otomatis menekankan gurunya untuk membekali peserta didik dengan materi kognitif yang berlimpah ruah (Sulistiyo, 2007). Alhasil, sempit ruang yang dimiliki guru untuk menggali potensi di luar kompetensi kognitif yang mungkin dimiliki siswa. Padahal, berdasarkan UU Sisdiknas tahun 2003 pasal 35, evaluasi peserta didik mencakupi kognitif, afektif, dan psikomotorik, sementara UN hanyalah bagian dari evaluasi kognitif semata. Dalam hal ini UN seharusnya tidak dapat dijadikan standar untuk menentukan kualitas pendidikan (Silverius, 2010).

Hal ini juga berdampak kepada orangtua siswa. Melihat tuntutan sekolah yang banyak menekankan materi dengan perangkat-perangkat penilaian kognitif, maka agar tidak kewalahan, tidak sedikit orangtua yang memasukkan anaknya ke lembaga/persona bimbingan belajar (Qomariyah et al., 2017). Akibatnya, bimbingan belajar (bimbel) menjamur di mana-mana. Menjamurnya bimbel menjadi barometer pendidikan kita belum dapat beranjak dari KBM ke KBK.

Sejatinya, di dalam Kurnas 2013, evaluasi dan tagihan penilaian secara ideal sudah mulai diurutkan (berdasar taksonomi Bloom) dari ranah psiko-motorik, kemudian ranah afektif (sikap), dan yang terakhir adalah ranah kognitif (intelektual). Namun hal ini sulit direalisasikan jika tagihan-tagihan penilaian kognitif masih ditekankan dan tersentralisasi oleh pusat. Padahal konteks satuan pendidikan di Indonesia sangat beragam (Silverius, 2010). Dalam beberapa kesempatan, penulis pernah menyaksikan langsung proses belajar mengajar di beberapa pulau terluar dari Provinsi Riau dan Provinsi Kepri. Satuan pendidikan di sana sangat terbatas, mulai dari tenaga pendidik, daya dukung, sampai kepada minimnya intaks peserta didik. Melihat hal ini, sudah jelas mereka akan "kalah banyak" jika mengikuti UN, dibandingkan dengan peserta didik dari kota-kota besar. Seharusnya ujian-ujian akhir dapat dikembalikan kepada satuan pendidikan tanpa mengabaikan pedoman yang telah diturunkan oleh pemerintah. Di sinilah pengawas sekolah dan asesor sekolah harus menjalankan fungsinya secara maksimal. 
Selain UN, untuk mata pelajaran (mapel) yang tidak di-UN-kan berlaku Ujian Sekolah Berstandar Nasional (USBN). Alih-alih ingin mengembalikan fungsi muatan lokal kepada satuan pendidikan, dalam praktiknya, USBN sama sekali tidak bersifat lokal. Kenyataannya USBN masih terikat pada regional tertentu, misalnya USBN provinsi atau kota/kabupaten. Padahal dalam satu provinsi atau kota/kabupaten sekolah sangat beragam dalam berbagai latar belakang dan konteks.

Sadar atau tidak, selama enam belas tahun, negara kita masih menjalankan pendidikan pola lama dengan label baru. Judulnya saja yang "berbasis kompetensi", tetapi isinya masih berbasis materi. Idealnya ingin menggali potensi peserta didik yang beragam, tapi realisasinya masih membekali siswa dengan materi yang seragam dengan sangat masif. Oleh sebab itu, lahirnya kebijakan Merdeka Belajar merupakan solusi yang baik untuk keluar dari kekangan paradigma dan praksis pola pendidikan yang lama. Gebrakan yang diajukan melalui kebijakan ini antara lain: pergantian model pelaksanaan UN, pergantian Ujian Sekolah Berstandar Nasional (USBN) menjadi ujian lokal satuan pendidikan, penyusunan RPP yang lebih ringkas, serta sistem zonasi dalam Penerimaan Peserta Didik Baru (PPDB). Dengan demikian, kebijakan Merdeka Belajar diharapkan dapat menjadi angin segar bagi para praktisi pendidikan, orangtua siswa, dan siswa itu sendiri, yang rindu akan pendidikan kontemporer sesuai dengan era kewirausahaan dan era revolusi industri 4.0.

Berkaitan dengan itu, penulis melihat peluang penerapan Merdeka Belajar yang efektif berdasarkan konsep-konsep yang tersari dari Teori Kritis Habermas. Asumsi penulis, bahwa melalui teori ini, kebijakan Merdeka Belajar dapat terwujud secara radikal dan berkelanjutan.

\section{2) Teori Kritis Habermas}

Teori Kritis Habermas merupakan generasi kedua dari Teori Kritis Mahzab Frankfurt. Generasi pertama Mahzab Frakfurt terdiri dari lima orang pemikir: Max Horkheimer, Theodor Adorno, Herbert Mercuse, Walter Benjamin, dan Erich Fromm. Teori Kristis generasi pertama dilandaskan pada pemikiran-pemikiran Karl Marx. Marx muda memiliki keprihatinan terhadap disintegrasi sosial yang dihasilkan oleh Pencerahan (Hardiman, 2003). Era Pencerahan dengan semangat rasionalitasnya telah menciptakan masyarakat modern yang individualistik. Modernisme yang dihasilkan oleh Pencerahan telah menciptakan kelas-kelas dalam masyarakat. Marx muda yang prihatin dengan keadaan sosial ini merekomendasikan sebuah reformasi untuk penghilangan status hak milik, dan berubah menjadi kepemilikan bersama. Kehidupan kepemilikan bersama yang teratur ini kemudian disebut sebagai paham sosialis. Marx yakin jika status hak milik dihilangkan, maka kelas-kelas strata sosial dapat juga dihilangkan (Hardiman, 2003). Dalam hal ini, masyarakat akan lebih emansipatoris dan terbebaskan. Konsep Marx ini yang kemudian hari dipakai oleh Uni Soviet sebagai falsafah dasar negara.

Dalam kaitan itu, Mahzab Frankfurt mengkritik penerapan Marxisme di Soviet, secara khusus di zaman kekuasaan Joseph Stalin. Marxisme seharusnya mengutamakan kaum proletar dan bersifat humanis. Namun di bawah Stalin, Soviet telah menjadi negara yang justru menindas rakyat dan tidak humanis. Dengan menggunakan kritik ideologi Marx, Mahzab Frankfurt mengkritisi penerapan Marxisme di Uni Soviet. Sebagian pemikir berpendapat bahwa Mahzab Frankfurt ini merupakan gerakan neo-Marxis.

Selain itu, Mahzab Frankfurt juga mengkritisi positivisme ilmu pengetahuan (yang pada waktu itu sedang berkembang pesat dalam dunia sains), secara khusus dalam kaitan dengan ilmu sosial kemanusiaan. Menurut mereka, ilmu sosial kemanusiaan tidak dapat memakai pendekatan positivisme, karena positivisme sarat dengan teoretis, padahal ilmu sosial kemanusiaan bukanlah ilmu alam dengan pola pemikiran biner. Positivisme telah mengkooptasi kemerdekaan manusia di dalam mengembangkan ilmu sosial kemanusiaan. Oleh karena itu Mahzab Frankfurt merekomendasikan suatu pendekatan yang lebih emansipatoris atau membebaskan, yaitu dengan refleksi diri. Dengan demikian, refleksi diri ini bertujuan untuk mengoreksi hal-hal yang kurang tepat dari modernisme, secara khusus tentang pemikiran positivisme yang diutarakan oleh para pemikir modernisme, serta terhadap disintegrasi sosial yang diakibatkan modernisme (Hardiman, 2003).

Budi Hardiman (2003) menyimpulkan bahwa dialektika refleksi diri yang dicetus Mahzab Frankfurt generasi yang pertama melahirkan kebingungan. Dialektika yang dimaksud berawal dari refleksi diri yang bertujuan membebaskan diri dari tradisi dan otoritas, namun di saat yang bersamaan, para pemikir Mahzab Frankfurt generasi pertama sangat senang dengan kegairahan dan kemajuan modernisme. Dalam perkembangannya, modernisme ini yang justru menumpulkan 
refleksi kritis di masyarakat. Di sinilah pusaran kebingungan itu muncul. Bagi Habermas, letak kegagalan para pendahulunya ada pada kurang jernihnya mereka dalam melakukan refleksi diri.

Dalam latar belakang yang demikian, Teori Kritis Habermas lahir. Teori Kritis Habermas disebut sebagai generasi kedua Teori Kritis Mahzab Frankfurt karena Habermas berhasil mempertajam pemikiran para pendahulunya, secara khusus tentang kritik terhadap positivisme, dan kritik ideologi. Tentang positivisme, Habermas sedikit bertolak belakang dengan para pendahulunya. Menurut Habermas, positivisme memiliki faedah tertentu dan tidak harus dibuang sepenuhnya. Misalnya, di dalam dunia kerja positivisme masih dapat dipakai untuk mengukur dan meningkatkan kualitas kerja. Akan tetapi, demikian Habermas, positivisme sama sekali tidak dapat diterapkan pada ilmu sosial kemanusiaan.

Tentang ilmu sosial kemanusiaan, Habermas berusaha untuk mencari relevansi antara teori dan praksis sosial. Mahzab Frankfrut generasi pertama menempatkan dunia kerja (istilah lain: "tindakan-rasional bertujuan") sebagai praksis sosial, padahal menurut Habermas dunia kerja harus dibedakan dengan kegiatan interaksi sosial. Bagi Habermas, komunikasilah yang dapat menjadi pintu praksis sosial. Praksis dunia kerja, demikian Habermas, bersifat mendominasi, sementara komunikasi sosial bersifat membebaskan (Hardiman, 2009). Motif utamanya sebenarnya adalah komunikasi intersubyektif yang ia minati sejak kecil. la memiliki cacat bibir sumbing dari sejak lahir, dan karena itu, ia sering mendapatkan perundungan dari teman-teman sekolahnya. Oleh karena itu komunikasi sosial merupakan dasar yang penting bagi seorang Habermas (Hardiman, 2015).

Habermas melihat dunia kerja lebih bersifat mekanik dan sudah diatur secara baku (default). Dunia kerja memiliki aturan-aturan teknis yang tidak dapat dilangkahi, sehingga manusia tidak dapat dengan bebas berasionalisasi dan bertindak. Sementara dalam komunikasi sosial, yang dijadikan target adalah pemahaman di antara dua belah pihak. Di dalam usaha memahami, rasionalisasi bersifat emansipatoris, sehingga manusia tidak terkooptasi sistem dan terbebaskan (Hardiman, 2009).

Selanjutnya, pembedaan antara dunia kerja dan dunia sosial semakin terlihat ketika proses rasionalisasi masuk ke dalam ranah aksi. Dari segi pelaku tindakan, menurut Habermas, pelaku tindakan dunia kerja berorientasi pada sukses. Sedangkan pelaku tindakan komunikatif berorientasi pada pencapaian pemahaman di antara dua belah pihak. Tindakan komunikatif seperti ini bersifat dua arah atau dialogal. Dialogal merupakan ciri khas praksis sosial Habermas, dimana kedua pihak bersifat emansipatoris dan tidak saling mendominasi (Hardiman, 2009: 9899).

Sekilas distingsi praksis sosial Habermas dalam sebuah tabel berikut ini.

Tabel 1. Perbedaan Praksis Dunia Kerja dan Komunikasi Sosial

\begin{tabular}{lll}
\hline & \multicolumn{1}{c}{$\begin{array}{c}\text { Dunia Kerja } \\
\text { (Tindakan Rasional Bertujuan) }\end{array}$} & \multicolumn{1}{c}{$\begin{array}{c}\text { Komunikasi Sosial } \\
\text { (Interaksi Sosial) }\end{array}$} \\
\hline Rasionalisasi & $\begin{array}{l}\text { Mekanik, mengikuti sistem yang sudah } \\
\text { default. }\end{array}$ & Emansipatoris \\
Komunikasi & $\begin{array}{l}\text { Monologal: hanya berdasarkan } \\
\text { instruksi }\end{array}$ & Dialogal: dua arah \\
Target & Sukses & Pemahaman \\
\hline
\end{tabular}

Lebih jauh lagi, komunikasi tidak dapat dilepaskan dengan ilmu hermeneutik. Habermas memang bukan seorang hermeneutisis dan tidak memiliki pemikiran yang orisinil tentang hermeneutik. Akan tetapi Habermas yang merupakan profesor di Frankfurt adalah orang yang gemar berdebat, lisan dan tulisan. la berdebat dengan banyak filsuf ternama, dan salah satunya adalah dengan Gadamer, seorang hermeneutisis. Perdebatan ini berlangsung cukup lama (19671972) dengan cara berbalas tulisan ilmiah. Melalui perdebatan panjang tersebut lahirlah kontribusi pemikiran hermeneutika Habermas. Memahami kontribusi hermeneutika Habermas berarti menjelaskan kembali pokok-pokok ketidaksepahaman Habermas atas hermeneutika Gadamer.

Ada dua pokok kritik Habermas terhadap Gadamer, yaitu: kritik terhadap konsep tradisi dan kritik terhadap klaim natur universal hermeneutika. Berkaitan dengan kritik yang pertama, terdapat tiga kata kunci hermeneutika Gadamer: prasangka, tradisi (dan otoritas), dan kesepahaman. Bagi Gadamer, memahami tidak bisa lepas dari prasangka. Bahkan menurutnya, prasangka merupakan pintu masuk memahami. Lanjut bagi Gadamer, memahami ada dalam 
ruang dan waktu, oleh sebab itu memahami tidak dapat melepaskan diri dari tradisi. Dan terakhir, bagi Gadamer, memahami adalah kesepahaman dengan tradisi (Hardiman, 2015).

Habermas tidak setuju dengan konsep memahami adalah kesepahaman dengan tradisi, karena tradisi dapat mengikat. Dalam hal ini, Habermas justru mengusulkan bahwa kita dapat berpisah dari tradisi. Hal ini dapat terjadi jika kita melakukan refleksi terhadap tradisi tersebut. Dalam ulasan Hardiman, mungkin pengalaman kehidupan Habermas dari pro-Nazi menjadi antiNazi yang mendasari pemikiran ini (2015).

Lagi menurut Habermas, bisa saja prasangka-prasangka diterima menjadi pengetahuan asalkan melewati proses refleksi. Baginya, menerima (kesepahaman dengan) tradisi tanpa refleksi bukanlah pengetahuan. Tentang hal ini Hardiman memberikan contoh bagaikan anak batita banyak melakukan hal-hal baru tanpa pengetahuan. la melakukannya karena tradisi yang diwariskan oleh orangtuanya. Di kemudian hari setelah orangtuanya menjelaskan barulah ia memahami (2015).

Pokok kritik yang kedua adalah di seputar persoalan klaim universalitas hermeneutika Gadamer. Menurut Gadamer semua ilmu di dunia ini memerlukan hermeneutika sebagai sarana memahami. Habermas tidak setuju akan hal ini. Ada bidang-bidang keilmuan yang tidak dapat dipahami melalui sarana hermeneutika, contohnya ilmu alam. Asumsi utama dalam berkomunikasi adalah diperlukannya dialog. Di dalam ilmu alam, kita tidak dapat melakukan dialog, yang ada hanya monolog, yaitu segala bentuk verifikasi dari alam (Hardiman, 2015). Menurut Habermas, hermeneutika tidak akan berfungsi dalam monolog.

Selain ilmu alam, terdapat hal lain lagi yang mana hermeneutika tidak dapat digunakan, yaitu pada teks-teks abnormal. Teks abnormal merupakan teks yang penulis/penuturnya sendiri bisa jadi tidak sadar dalam mengartikulasikannya. Menurut Habermas, teks abnormal itu hadir di dalam konteks psikopatologi dan indoktrinasi. Untuk konteks itu hermeneutik biasa tidak dapat berlaku. Diperlukan Hermeneutik Kritis untuk mengatasi teks-teks abnormal (Hardiman, 2015).

Dalam menerapkan hermeneutika kritis, Habermas mengadopsi konsep psikoanalisis Freud, yang la gunakan untuk mengatasi permasalahan psikopatologis, dan mengadopsi konsep kritik ideologi Marx untuk mengatasi permasalahan indoktrinasi. Sasaran hermeneutika kritis adalah menemukan motif yang tidak disadari penulis. Dengan psikoanalisis Freud, Habermas berteori bahwa teks yang rusak (abnormal) dapat direkonstruksi kembali. Seorang psikiater bertugas untuk menyusun kembali teks-teks yang rusak tersebut melalui sesi-sesi yang panjang yang terpisah-pisah. Kemudian psikiater mencoba menggabungkannya dan menghasilkan cerita yang lebih utuh. Lalu psikiater menceritakan teks yang sudah terekonstruski kepada penulis/penutur yang psikopat tadi. Tujuannya agar si penulis yang mengalami gangguan jiwa tersebut dapat berefleksi (Hardiman, 2015). Jadi, hanya melalui hermeneutik kritis ini, si penulis/penutur yang adalah sumber dapat diajak untuk berefleksi.

Sedangkan dalam konteks indoktrinasi, kita dapat melihat kembali kepada kritik ideologi Marx dalam kaitannya dengan problema sosial yang dihadirkan oleh modernisme, sebagaimana yang telah dijelaskan sebelum ini. Secara garis besar, indoktrinasi bersifat monologal dan mendominasi, sehingga sulit untuk mencapai pemahaman yang ideal. Kritik ideologi Marx bersifat membebaskan rasionalisasi dari sifat indoktrinasi satu arah tersebut. Namun hal ini bukan berarti pemikiran bersifat bebas sebebas-bebasnya. Dalam hal ini refleksi diri dapat memainkan perannya, apakah suatu pemikiran proporsional atau tidak.

Secara singkat, Teori Kritis Habermas bertujuan untuk membebaskan pemikiran dan tindakan dari sistem yang mengikat, dan dari sifat monologal komunikasi. Melalui Teori Kritis, pengetahuan dapat dipahami sebagai sesuatu yang otentik dalam konteks subjek pemikirnya, bukan sebagai pemikiran yang terikat yang diteruskan turun temurun.

\section{b. Pembahasan: Menerapkan Teori Kritis Habermas sebagai Usaha Kontinuitas Kebijakan Merdeka Belajar}

Melihat pemaparan Teori Kritis di atas, penulis melihat beberapa bagian yang dapat dikorelasikan, dan kemudian diakomodasikan dalam penerapan kebijakan baru Merdeka Belajar yang dicanangkan oleh Mendikbud. Penulis akan mencoba untuk mendialogkan bagian-bagian yang dapat dikorelasikan berdasarkan realitas dan kesenjangan penerapan KBK sebagaimana yang telah dijelaskan dalam sub-hasil penelitian tentang "Urgensi Merdeka Belajar" di atas.

\section{1) Relevansi Teori Kritis Haberms dalam kaitan dengan pergantian UN atau model UN}

Sejak awal kepemimpinannya, Menteri Makarim merekomendasikan untuk tidak melanjutkan pelaksanaan UN. Menurutnya, materi UN terlalu padat sehingga siswa dan guru cenderung menguji penguasaan materi, dan bukan kompetensi penalaran (Adit, 2019). Untuk itu, 
Makarim merekomendasikan UN diganti dengan Asesmen Kompetensi Minimum (AKM) dan survei karakter.

AKM merupakan penilaian kompetensi mendasar yang diperlukan oleh semua murid untuk mampu mengembangkan kapasitas diri dan berpartisipasi positif pada masyarakat. Terdapat dua kompetensi mendasar yang diukur AKM: literasi membaca dan literasi matematika (numerasi). AKM menyajikan masalah-masalah dengan beragam konteks yang diharapkan mampu diselesaikan oleh peserta didik menggunakan kompetensi literasi membaca dan numerasi yang dimilikinya. AKM dimaksudkan untuk mengukur kompetensi secara mendalam, tidak sekedar penguasaan konten (Kemendikbud, 2020a). AKM memberikan kebebasan kepada peserta didik untuk bernalar sesuai kebutuhannya dan kebutuhan konteks dimana ia tinggal.

Sedangkan survei karakter merupakan asesmen yang dipakai untuk untuk mengukur capaian peserta didik dari hasil belajar etika dan sosial berupa pilar-pilar karakter untuk mencetak output Profil Pelajar Pancasila. Profil Pelajar Pancasila, menurut Makarim, adalah peserta didik yang beriman dan bertakwa kepada Tuhan YME serta berakhlak mulia, berkebhinekaan global, mandiri, bergotong royong, bernalar kritis, dan kreatif (Kemendikbud, 2020b).

AKM dan survei karakter dimaksudkan supaya setiap satuan pendidikan dapat menentukan model pembelajaran yang lebih cocok untuk peserta didik di daerah tertentu, dan yang sesuai dengan kebutuhan pembelajaran mereka (Kemendikbud, 2020c). Dengan demikian, AKM tidak akan sekaku UN.

Dari penjelasan singkat di atas, maka kebijakan pergantian UN menjadi AKM dan survei karakter adalah sejalan dengan pemikiran Teori Kritis Habermas. Dari Teori Kritis Habermas didapati bahwa setiap individu seharusnya dapat mengembangkan kemampuan berasionalisasi berdasarkan minat dan konteks latar belakang kehidupannya. Artinya, kemampuan seseorang dalam bernalar tidak diatur berdasarkan sistem dan konten yang telah diatur secara otoritatif.

Waidl, seorang praktisi pendidikan, mengatakan bahwa Teori Kritis dapat dijadikan landasan metodologi pendidikan di Indonesia. Menurutnya, Teori Kritis memberikan kesempatan seseorang (siswa) untuk mengembangkan kemampuan berpikirnya. Setelah itu, pokok-pokok pikirannya dapat diaktualisasikan dan kemudian direinterpretasikan ke dalam permasalahan yang aktual. Proses aktualisasi dan reinterpretasi ini akan menghadirkan dialog. Dengan adanya dialog, maka dominasi dapat dihentikan (Waidl, 2000).

Sebagai simpulan singkat, UN merupakan cerminan sistem dan pendistribusian materi yang seragam dan kaku. Selama ini, kegagalan peserta didik di dalam mengikuti UN dapat dianggap sebagai kebodohan. Padahal bisa jadi kegagalan seorang peserta didik di dalam UN disebabkan karena minat dan latar belakang peserta didik yang berbeda jauh dari materi UN yang sentralistik tersebut. Habermas jelas menentang sistem seperti ini, karena sistem seperti ini telah mengkooptasi rasionalisasi individu dan menghilangkan sisi orisinalitas pemikiran individu.

Dalam menjalankan AKM dan survei karakter, sebaiknya pendidik, satuan pendidikan, peserta didik, dan orangtua siswa dapat memperhatikan prinsip-prinsip Teori Kritis Habermas yang memberikan kebebasan dalam berasionalisasi dan yang bersifat emansipatoris dalam berpikir dan bertindak.

\section{2) Relevansi Teori Kritis Habermas dalam kaitan dengan perubahan pelaksanaan USBN}

Pada tanggal 10 Desember 2019, Menteri Makarim mengeluarkan Peraturan Menteri (Permendikbud) no. 43 tahun 2019 tentang Penyelenggarakan Ujian yang Diselenggarakan Sekolah dan Ujian Nasional. Pada pasal 2 ayat 1 diatur bahwa ujian yang diselenggarakan oleh satuan pendidikan merupakan penilaian hasil belajar oleh satuan pendidikan yang bertujuan untuk menilai pencapaian standar kompetensi lulusan untuk semua mata pelajaran. Dan dalam pasal 6 ayat 2 diatur bahwa untuk kelulusan peserta didik ditetapkan oleh satuan pendidikan/program pendidikan yang bersangkutan. Dari pasal-pasal dan ayat-ayat di atas tersirat bahwa USBN akan dikembalikan pelaksanaannya secara mandiri oleh satuan pendidikan.

Kebijakan ini juga sejalan dengan pemikiran Teori Kritis Habermas. Habermas menolak sistem yang memiliki ciri indoktrinasi monologal. Pemahaman dalam indoktrinasi monologal bersifat sentralistik dan mendominasi. Penyelenggaraan USBN selama ini bercirikan demikian, sentralistik dan mendominasi. Alih-alih ingin mengeskalasi muatan lokal, namun dalam praktiknya soal-soal ujian merupakan garapan pusat. Dalam hal ini ada kesenjangan penerapan pendidikan nasional.

Dengan adanya Permendikbud no. 43 ini, maka apresiasi terhadap muatan lokal dapat kembali terwujud. Para pemangku kepentingan pendidikan kiranya dapat terus melakukan apresiasi ini. Indonesia memiliki daerah yang kaya ragam, dan sangat disayangkan jika USBN masih tersentralisasi, karena hal tersebut akan mematikan pengoptimalan budaya dan pemikiran 
lokal. Oleh karena itu, saran penulis, para pemangku kepentingan pendidikan dapat terus mengingat konsep pemikiran Teori Kritis Habermas yang menolak indoktrinasi, sentralisasi, dan pengetahuan yang bersifat monologal.

\section{3) Relevansi Teori Kritis Habermas dalam kaitan dengan peringkasan Rencana Pelaksanaan Pembelajaran (RPP)}

Surat Edaran Mendikbud no. 14 Tahun 2019 tentang Penyederhanaan RPP, yang juga diterbitkan pada 10 Desember 2019, berisi antara lain: (1) penyusunan RPP dilakukan dengan prinsip efisien, efektif, dan berorientasi pada siswa; (2) Dari 13 komponen RPP yang tertuang dalam Permendikbud Nomor 22 Tahun 2016, yang menjadi komponen inti adalah tujuan pembelajaran, langkah-langkah pembelajaran, dan penilaian pembelajaran yang wajib dilaksanakan oleh pendidik, sedangkan sisanya hanya sebagai pelengkap.

Dari surat edaran di atas terlihat jelas usaha Kemendikbud saat ini untuk merombak aturan yang bersifat teknokratis dan birokratis. Sebelumnya, pendidik banyak disibukkan dengan penyusunan administrasi guru, termasuk RPP, yang sangat banyak dan memakan waktu. Alhasil, pendidik kekurangan waktu untuk memikirkan bahan ajar yang kreatif dan konstruktif. Sehingga pada akhirnya, pendidik lebih banyak mentransfer materi yang sudah ada dalam buku paket, dan menginstruksikan peserta didik untuk mengerjakan lembar kerja yang juga terdapat dalam buku paket tersebut. Jadi secara tidak langsung peserta didik justru lebih banyak menerima informasi dari buku paket, yang secara bebas dapat diperoleh juga di media internet.

Dalam penerapan penyusunan dan pelaksanaan RPP selanjutnya, sesuai dengan instruksi surat edaran Kemendikbud no. 14, penulis mengusulkan agar para pendidik dapat memperhatikan konsep interaksi sosial Habermas. Sebagaimana dalam penjelasan sebelumnya, Habermas menolak praksis sosial dunia kerja yang bersifat mekanik sesuai dengan sistem yang baku. la juga menolak komunikasi yang bersifat monologal, dan sebagai gantinya, Habermas merekomendasikan komunikasi dialogal emansipatoris.

Dua kriteria dari Habermas ini seharusnya dapat menolong pendidik untuk menyusun RPP sesuai kebutuhan siswa dan satuan pendidikan setempat. Dan di dalam mengembangkan struktur RPP, pendidik juga dapat dengan kreatif menyusun dan menerapkan pembelajaran yang bersifat emansipatoris (membebaskan). Selain itu, pendidik dapat juga membebaskan diri dari budaya masa lalu yang mengikat pendidik untuk menyusun RPP yang rumit dan memakan waktu.

\section{4) Relevansi Teori Kritis Habermas dalam kaitan dengan perubahan paradigma KBM ke KBK}

Bagian terakhir ini, menurut penulis, merupakan inti yang mendasari dan merangkumkan pertautan antara kebijakan Merdeka Belajar dengan Teori Kritik Habermas. Sedari awal esai ini, penulis memiliki keprihatinan yang kuat terhadap pelaksanaan KBK yang sangat tidak optimal. Sebagai praktisi di dunia pendidikan, penulis memperhatikan dengan seksama bahwa tubuh KBK masih dioperasikan dengan jiwa KBM. Mayoritas satuan pendidikan, pendidik, dan orangtua siswa tetap setia dengan pemahaman bahwa materi adalah dasar pengetahuan. Artinya, selama enam belas tahun ini (setidaknya lima belas tahun, karena setahun terakhir dunia dilanda pandemi), implementasi KBK belum sepenuhnya berjalan. Perlu sesuatu yang radikal untuk mengubah paradigma yang lama menjadi baru.

Untuk itu penulis merekomendasikan Teori Kritis Habermas, secara khusus dalam kaitannya dengan ketidaksepahaman terhadap hermeneutika Gadamer. Bagi Gadamer pemahaman adalah kesepahaman dengan tradisi dan otoritas. Sebagaimana yang telah dijelaskan, Habermas menolak pemikiran Gadamer tentang tradisi dan otoritas tersebut. Menurut Habermas, refleksi kritis seseorang dapat memutuskan dirinya dari tradisi dan otoritas. Contoh praktis dalam kehidupan Habermas adalah ketika ia berubah haluan dari seorang pro-Nazi menjadi seorang anti-Nazi. Sekilas, dengan cara demikian, perubahan paradima pendidikan juga dapat terjadi.

Beberapa keputusan Kemendikbud yang dikeluarkan untuk memantapkan kebijakan Merdeka Belajar, menurut penulis, cukup strategis bagi ranah praktis. Namun perlu suatu spirit yang benar-benar menggerakan secara radikal langkah-langkah strategis pemerintah. Saran penulis, para praktisi pendidikan sebaiknya mampu melakukan refleksi kritis Habermas untuk melihat apakah tradisi dalam dunia pendidikan masih proporsional atau tidak, kontekstual atau tidak, serta tepat sasaran atau tidak. Jika tidak, maka tradisi tersebut harus diputus dan diganti dengan yang baru. Refleksi dan evaluasi ini seharusnya berkelanjutan, sehingga pembaruan tidak mengalami stagnansi. Tidak tertutup kemungkinan kebijakan Merdeka Belajar saat ini, juga akan dibarui dalam masa mendatang. Ini merupakan ciri refleksi kritis Habermas bahwa 
pembaruan dapat berkesinambungan. Spirit ini yang kiranya dapat terus menggerakkan pembaruan dalam dunia pendidikan di Indonesia.

Pada kesempatan berbeda, Habermas juga menuliskan bahwa perubahan (ideologi atau paradigma) tidak mungkin dilakukan tanpa merevolusionerkan ilmu dan teknik itu sendiri. Perubahan ke arah kemajuan dapat dilakukan dengan memutuskan ikatan yang fatal terhadap ilmu pengetahuan (Habermas, 1990). Jadi, demi terjadinya perubahan, kita perlu memutuskan ikatan tradisi yang membungkam ilmu pengetahuan untuk berkembang.

\section{Simpulan dan Saran}

Kebijakan Merdeka Belajar merupakan angin segar bagi para praktisi pendidikan dan peserta didik yang mendambakan sistem pembelajaran yang emansipatoris dan membangun kompetensi siswa, secara khusus di dalam konteks era kewirausahaan dan era revousli industri 4.0. Implementasi yang optimal dan efektif dari kebijakan Merdeka Belajar telah menjadi tuntutan tersendiri agar kebijakan ini tidak bersifat temporer.

Banyak hal yang harus dipikirkan dan diterapkan agar pemangku kepentingan pendidikan dapat mengimplementasikan Merdeka Belajar dengan baik. Dari penelitian di atas ditemukan bahwa Teori Kritis Habermas adalah sangat sejalan dengan kebijakan Merdeka Belajar, sehingga dapat dijadikan pedoman alternatif di dalam menjalankan kebijakan tersebut. Diharapkan melalui konsep-konsep yang diutarakan dalam Teori Kritis Habermas, beberapa gebrakan kebijakan Merdeka Belajar dapat berjalan dengan efektif, seperti: pergantian pelaksanaan UN, pergantian USBN, dan penyederhanaan RPP. Juga melalui Teori Kristis Habermas, paradigma para pemangku kepentingan pendidikan dapat beranjak dari paradigma pendidikan yang lama kepada paradigma baru sesuai dengan tuntutan zaman. Penulis menyarankan agar Teori Kritis Habermas dapat dijadikan jiwa dari kebijakan Merdeka Belajar, agar natur pembaruan dari kebijakan ini dapat berkesinambungan.

\section{Daftar Pustaka}

Adit, A. (2019, December 12). Gebrakan "Merdeka Belajar”, Berikut 4 Penjelasan Mendikbud Nadiem. Kompas. https://edukasi.kompas.com/read/2019/12/12/12591771/gebrakanmerdeka-belajar-berikut-4-penjelasan-mendikbud-nadiem?page=all.

Depdikbud. (1979). Belajar adalah Berubah. Jakarta: Dirjen Pendidikan Tinggi.

Fuaddudin. (2020). "Perubahan Paradigma Mengajar Guru dalam Menyongsong Penyelenggaraan Pendidikan di Era Revolusi Industri 4.0". El-Muhbib: Jurnal Pemikiran Dan Penelitian Pendidikan Dasar, vol. 4, no. 1. Hal. 68-81. https://doi.org/https://doi.org/10.52266/el-muhbib.v4i1.478.

Habermas, J. (1990). IImu dan Teknologi sebagai Ideologi. Jakarta: LP3ES.

Hardiman, B. (2003). Melampaui Positivisme dan Modernitas. Yogyakarta: Kanisius.

Hardiman, B. (2009). Kritik Ideologi: Menyingkap Pertautan Pengetahuan dan Kepentingan bersama Jürgen Habermas. Yogyakarta: Kanisius.

Hardiman, B. (2015). Seni Memahami: Hermeneutik dari Schleiermacher sampai Derrida. Yogyakarta: Kanisius.

Kemendikbud. (2020a). Asesmen Kompetensi Minimum. Kemdikbud.Go.Id. https://hasilun.puspendik.kemdikbud.go.id/akm/frontpage/detail.

Kemendikbud. (2020b). Asesmen Nasional sebagai Penanda Perubahan Paradigma Evaluasi Pendidikan. Kemdikbud.Go.ld. https://www.kemdikbud.go.id/main/blog/2020/10/asesmennasional-sebagai-penanda-perubahan-paradigma-evaluasi-pendidikan

Kemendikbud. (2020c). Merdeka Belajar. Kemdikbud.Go.Id. https://gtk.kemdikbud.go.id/readnews/merdeka-belajar.

Qomariyah, A., Fatimah, N., \& Rochana, T. (2017). "Melanggengkan Bimbingan Belajar dalam Kapitalisme Pendidikan". Solidarity, vol. 6, no. 1. https://journal.unnes.ac.id/sju/index.php/solidarity/article/view/15630.

Silverius, S. (2010). "Kontroversi Ujian Nasional Sepanjang Masa". Jurnal Pendidikan Dan Kebudayaan, vol. $16, \quad$ no. $2 . \quad$ Hal. $194-205$. https://doi.org/https://doi.org/10.24832/jpnk.v16i2.446. 
Sudiarta, I. G. P. (2003). "Mencermati Kurikulum Berbasis Kompetensi: Sebuah Kajian Epistemologis dan Praktis". Jurnal Pendidikan Dan Pengajaran IKIP Negeri Singaraja, vol. 36, no.1. Hal. 32-50. https://nanopdf.com/download/menyukseskan-kbk-dengan-konseplearning-school_pdf.

Sulistiyo, G. (2007). "Ujian Nasional (UN): Harapan, Tantangan, dan Peluang". Wacana: Jurnal IImu Pengetahuan Dan Budaya, vol. 9, no. 1. Hal 79-106. http://wacana.ui.ac.id/index.php/wjhi/article/view/224/213.

Sumarno, \& Gimin. (2019). "Analisis Konseptual Teoretik Pendidikan Kewirausahaan sebagai Solusi Dampak Era Industri 4.0 di Indonesia". Jurnal Pendidikan Ekonomi: Jurnal IImiah IImu Pendidikan, IImu Ekonomi, Dan IImu Sosial, vol. 13, no. 2. Hal. 1-14. https://doi.org/10.19184/jpe.v13i2.12557.

Waidl, A. (2000). "Pendidikan yang Memahami Manusia". Dalam A. Atmadi \& Y. Setiyaningsih (Eds.), Transformasi Pendidikan Memasuki Milenium Ketiga. Yogyakarta: Kanisius. 